\title{
Genetic Diversity of Thread-sail Filefish Stephanolepis cirrhifer Populations in Korean Coastal Waters Inferred from Mitochondrial DNA Sequence Analysis
}

\author{
Moongeun Yoon, Ju-Yeon Jung, Yoon Kwon Nam and Dong Soo Kim* \\ Institute of Marine Living Modified Organisms, Pukyong National University, \\ Busan 608-737, Korea
}

\begin{abstract}
The genetic diversity and population genetic structure of thread-sail filefish, Stephanolepis cirrhifer (Temminck \& Schlegel), were examined with a nucleotide sequence analysis of a $495 \mathrm{bp}$ fragment of the $5^{\prime}$-end of the cytochrome $b$ gene in 113 fish collected from five populations from the south and east coasts of the Korean Peninsula. Seventeen variable nucleotide sites and 16 haplotypes were defined. The observed haplotypes had a shallow haplotype genealogy and no geographical association. Most of the populations had high haplotype diversity and low nucleotide diversity, and significant negative values for Fu's $F_{S}$, suggesting rapid, recent population growth from an ancestral population and sudden population expansion. The estimated pairwise fixation indices $\left(F_{\mathrm{ST}}\right)$ indicate that substantial gene flow occurs among these populations. Thread-sail filefish in the South Sea of Korea and East Sea Korean populations forms a single panmictic population. Thus, thread-sail filefish in these areas should be treated as one management unit.
\end{abstract}

Key words: Cytochrome $b$ gene, Management unit, Population structure, Sea currents, Stephanolepis cirrhifer

\section{Introduction}

Thread-sail filefish Stephanolepis cirrhifer (Temminck \& Schlegel) is an economically important fish species that is widely distributed in the western Pacific Ocean (Masuda et al., 1984; Youn, 2002). It is mostly captured in the coastal areas of the Korean Peninsula, south Japan, and China in the East China Sea, mostly in the Kuroshio Current from the tropical Pacific Ocean. In 1985, the S. cirrhifer catch exceeded 250,000 tonnes in the Northwest Pacific, but this decreased rapidly to less than 350 tonnes in 2002 (FAO, 2004). Stocks of this species have been decreasing as a result of overfishing and changes in its environment. This situation makes it urgent to evaluate the biological and genetic characteristics of $S$. cirrhifer populations to maintain genetic variation, allowing the sustainable harvest of this species.

Genetic variation is important for the long-term survival of natural populations because it confers the ability to adapt to environmental changes, thereby increasing the fitness of the population (Frankel and

\footnotetext{
*Corresponding author: dongskim@pknu.ac.kr
}

Soule 1981). Indeed, the structure of fish populations has attracted considerable interest because of its importance for the management of fisheries (Bailey, 1997; Zhang et al., 2006). The estimation of population genetic structure using molecular markers is now commonly used to understand the dynamics of natural populations, especially resource recovery, and to monitor populations for fisheries management and conservation purposes. The population genetic structures of marine fishes are influenced by their larval behavior and dispersal patterns, which are determined by oceanographic features, such as sea currents, hydrological conditions, and physical barriers (Doyle et al., 1993; Umino et al., 2009; Hsieh et al., 2010; Kim et al., 2010). Most marine species have limited intraspecific population structures and high levels of gene flow influenced by sea currents (Palumbi, 1994; Sekino and Hara, 2001; Kochzius and Blohm, 2005; Song et al., 2010). However, little is known about the genetic structure of S. cirrhifer in the Pacific Ocean.

Nucleotide sequence information from maternally inherited mitochondria DNA (mtDNA) genes is useful for investigating inter- and intraspecific 
genetic variation among closely related taxa, species, or regional populations (Moritz et al., 1987: Avise, 1994). The cytochrome $b$ gene (Cytb), which contains both conserved and variable sites, is a useful marker for assessing the genetic structure of fish populations (Grant and Bowen, 1998; Hamner et al., 2007; Hwa et al., 2009).

This study examined the genetic variation and population structure of $S$. cirrhifer along the Korean coast using sequence analysis of the mtDNA Cytb gene to obtain basic data for fisheries resources management.

\section{Materials and Methods}

\section{Samples and DNA extraction}

Stephanolepis cirrhifer samples were collected from five sites located on two coastlines (the south (3 sites) and east ( 2 sites) coasts) of Korea in 2009 and 2010 (Table 1, Fig. 1). Collected samples were stored at $-20^{\circ} \mathrm{C}$ or kept in $100 \%$ ethanol at room temperature until use. Genomic DNA was extracted using a conventional SDS/proteinase $\mathrm{K}$ method, followed by organic extraction and ethanol precipitation (Sambrook and Russell, 2001). Purified DNA was dried at room temperature, and then dissolved in TE buffer (10 mM Tris-HCl, 1 mM EDTA, pH 8.0).

Table 1. Sampling sites, and dates, geographical coordinates and number of examined individuals $(N)$ in five Stephanolepis cirrhifer populations

\begin{tabular}{|c|c|c|c|c|}
\hline \multirow{2}{*}{$\begin{array}{l}\text { Sampling } \\
\text { site }\end{array}$} & \multirow{2}{*}{$\begin{array}{l}\text { Date of } \\
\text { collection }\end{array}$} & \multicolumn{2}{|c|}{ Geographical co-ordinates } & \multirow{2}{*}{$N$} \\
\hline & & Latitude & Longitude & \\
\hline Jeju & Aug. 2010 & $33^{\circ} 03^{\prime} 14.54 " \mathrm{~N}$ & $126^{\circ} 32^{\prime} 39.67^{\prime \prime E}$ & 20 \\
\hline Yeosu & Aug. 2010 & $34^{\circ} 41^{\prime 22.99 " N}$ & $127^{\circ} 39^{\prime} 59.62 " \mathrm{E}$ & 24 \\
\hline Geoje & July 2010 & $34^{\circ} 43^{\prime} 15.11^{\prime \prime} \mathrm{N}$ & $128^{\circ} 41^{\prime} 07.46 " \mathrm{E}$ & 24 \\
\hline Pohang & Oct. 2010 & $36^{\circ} 02^{\prime} 50.30 " \mathrm{~N}$ & $129^{\circ} 24^{\prime} 31.75^{\prime \prime E}$ & 21 \\
\hline Uljin & Oct. 2009 & $36^{\circ} 58^{\prime} 04.20^{\prime \prime} \mathrm{N}$ & $129^{\circ} 26^{\prime} 09.39^{\prime \prime} \mathrm{E}$ & 24 \\
\hline Total & & & & 113 \\
\hline
\end{tabular}

\section{Nucleotide sequence analysis}

The polymerase chain reaction (PCR) was used to amplify the mtDNA Cytb gene with the newly designed primers StepCytbF (5'-CCGGAACTAATG ACTTGAAA-3') and StepCytbR (5'-AGCATTGTCT ACCGAGAAGCC-3') based on the complete mitogenomic sequence of $S$. cirrhifer available in GenBank (NC_003177). PCR amplification was performed with a DNA Engine thermocycler (MJ Research, Tokyo, Japan) in $20 \mu \mathrm{L}$ reactions containing 1-2 $\mu \mathrm{g}$ of genomic DNA, $2 \mu \mathrm{M}$ of each primer, $0.25 \mathrm{mM}$ of each dNTP, 1 unit of TaKaRa LA Taq DNA polymerase (TaKaRa Shuzo, Shiga, Japan),

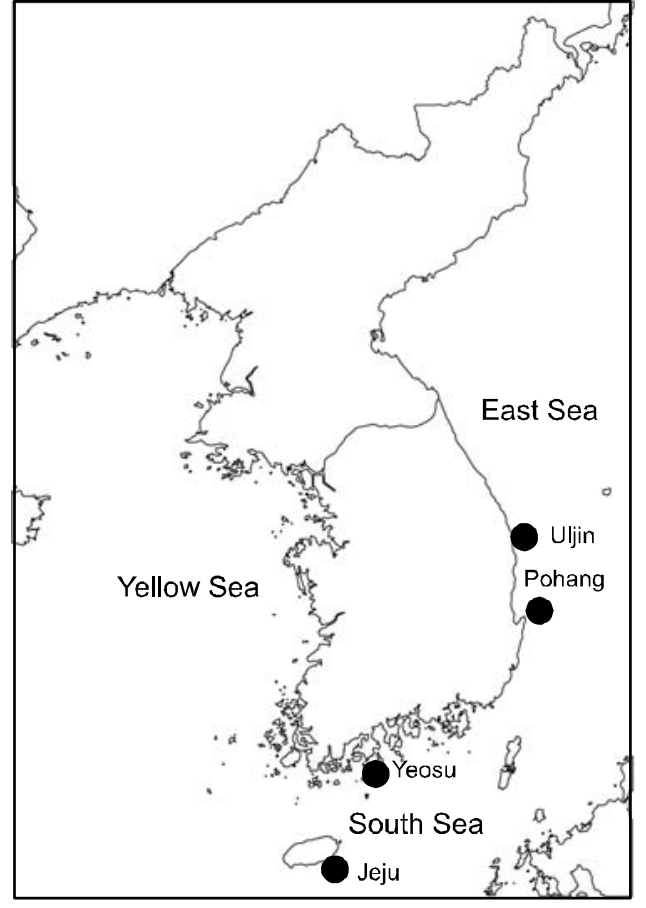

Fig. 1. Sampling locations of the five Stephanolepis cirrhifer populations analyzed in this study.

and $2 \mu \mathrm{L}$ of $10 \times$ LA Taq reaction buffer (TaKaRa Shuzo). PCR conditions consisted of preheating at $94^{\circ} \mathrm{C}$ for $5 \mathrm{~min}$, followed by 35 cycles of $94^{\circ} \mathrm{C}$ for 30 $\mathrm{s}, 55^{\circ} \mathrm{C}$ for $30 \mathrm{~s}$, and $72^{\circ} \mathrm{C}$ for $30 \mathrm{~s}$, with a final 5 min extension at $72^{\circ} \mathrm{C}$. Size of the PCR product was verified by $1.5 \%$ agarose gel electrophoresis after ethidium bromide staining. The PCR product was purified with the AccuPrep PCR Purification Kit (Bioneer, Daejeon, Korea). After cycle sequencing with the ABI PRISM BigDye Terminator v3.1 Cycle Sequencing Ready Reaction Kit (Applied Biosystems, Foster City, CA, USA), the purified PCR product was sequenced directly on an ABI 3730xl DNA Analyzer (Applied Biosystems) with the same primers.

\section{Data analysis}

Sequence data were aligned using DnaSP (ver. 4.90.1; Rozas and Rozas, 1997) to examine the haplotypes of the Cytb gene. A parsimony network connecting the observed haplotypes was plotted with TCS (ver. 1.21; Clement et al., 2000) to resolve their genealogy. The haplotype diversity $(h)$ and nucleotide diversity $(\pi)$ within the populations were estimated according to Nei (1987), based on Kimura's twoparameter distance method, using $\mathrm{K}$ and DA in the program REAP (McElroy et al., 1993).

Pairwise population $F_{\mathrm{ST}}$ values were calculated to estimate the genetic differentiation between popula- 
tions, according to Slatkin and Hudson (1991), using the program Arlequin (ver. 3.1; Excoffier et al., 2005). The significance of each $F_{\mathrm{ST}}$ value was tested using 10,000 random permutations. Analysis of molecular variance (AMOVA) was used to test for population structure with Arlequin (ver. 3.1). Neutral expectation and historic demographic expansions were investigated by examining Fu's $F_{S}$ and Tajima's $D$ and mismatch distributions with the sudden expansion model (Rogers and Harpending 1992). Both the neutrality test and mismatch distribution analysis were performed in Arlequin (ver. 2000; Schneider et al., 2000).

\section{Results and Discussion}

Sequence analysis of a $495 \mathrm{bp}$ fragment of the $5^{\prime}$ end of the Cytb gene detected 17 variable nucleotide sites among 113 individuals, defining a total of 16 haplotypes (Table 2). All of the substitutions at each site were biallelic, suggesting the occurrence of a single base substitution between sequences and no saturation of the substitutions, except at one site that was triallelic. A network diagram of the 16 observed haplotypes is shown in Fig. 2; the circle sizes reflect the haplotype abundances in the study areas. The focal haplotype, Hap1, was abundant, whereas the other haplotypes were rare and most likely derived from the focal haplotype, suggesting a shallow haplotype genealogy. The haplotype network had a star-like shape. The focal haplotype was common in all populations, while the genealogically related haplotypes were scattered throughout all populations
(Table 3), suggesting that the observed haplotypes did not provide evidence of geographical association. The haplotype and nucleotide diversities are shown in Table 4 . The average haplotype diversity was 0.517 and the average nucleotide diversity was 0.00153 , indicating that the $S$. cirrhifer populations examined have high haplotype and low nucleotide diversities. Thus, a shallow haplotype genealogy and the star-like shape pattern, and high level of haplotype diversity, but low nucleotide diversity within populations suggest the recent appearance and rapid population growth from an ancestral population with a small effective population size (Slatkin and Hudson, 1991; Rogers and Harpending, 1992; Avise, 2000).

Fixation indices, based on mitochondrial haplotypes, showed no significant genetic differentiation between any population pair (Table 5), perhaps as a result of the high gene flow. Results of AMOVA were also not significant for the South Sea or East Sea Korean populations, suggesting that no population structure existed throughout the examined range of $S$. cirrhifer. These results suggest that $S$. cirrhifer in the South Sea and East Sea forms a single panmictic population. Indeed, large numbers shared the focal haplotype, suggesting that they arose from one large breeding population. Low genetic diversity in the Uljin population, from the northern-most East Sea, in comparison with the southern populations was observed in both the haplotype and nucleotide diversities. Indeed, this population has no genetic differentiation from southern populations, inferred from pairwise $F_{\mathrm{ST}}$ values (Table 5). Thus, the $S$. cirrhifer population in Uljin may be subject con-

Table 2. Variable nucleotide sites in the mitochondrial DNA Cytb gene (495 bp) and the defined haplotypes of Stephanolepis cirrhifer

\begin{tabular}{|c|c|c|c|c|c|c|c|c|c|c|c|c|c|c|c|c|c|}
\hline \multirow{2}{*}{ Haplotype } & \multicolumn{17}{|c|}{ Variable nucleotide sites } \\
\hline & 41 & 56 & 86 & 98 & 134 & 137 & 140 & 155 & 161 & 211 & 215 & 245 & 263 & 317 & 344 & 377 & 431 \\
\hline Hap1 & $\mathrm{C}$ & $A$ & $\mathrm{~T}$ & $\mathrm{G}$ & $\mathrm{G}$ & $\mathrm{T}$ & $\mathrm{C}$ & G & $\mathrm{G}$ & $A$ & $A$ & G & $\mathrm{G}$ & G & $\mathrm{T}$ & $A$ & $\mathrm{G}$ \\
\hline Hap2 & . & . & $\cdot$ & . & . & . & . & . & . & . & . & $A$ & $\cdot$ & . & . & . & . \\
\hline Hap3 & . & . & . & . & . & . & . & . & . & . & . & . & A & . & . & . & . \\
\hline Hap4 & . & . & . & . & . & . & $\mathrm{T}$ & . & . & . & . & . & . & . & . & . & . \\
\hline Hap5 & . & . & . & . & . & . & . & . & . & . & . & . & . & $A$ & . & . & . \\
\hline Hap6 & $\mathrm{T}$ & . & . & . & . & . & . & . & . & . & . & $A$ & . & . & . & . & . \\
\hline Hap7 & . & $G$ & . & . & . & . & . & . & . & . & $\mathrm{T}$ & . & . & . & . & . & . \\
\hline Hap8 & . & . & . & . & . & . & . & . & $A$ & . & . & . & . & . & $\cdot$ & . & . \\
\hline Hap9 & . & . & . & . & . & C & . & . & . & . & . & . & . & . & . & . & . \\
\hline Hap10 & . & . & . & . & . & $A$ & . & . & . & . & . & . & . & . & . & . & . \\
\hline Нар11 & . & . & $\cdot$ & $\cdot$ & . & $\cdot$ & . & $A$ & . & . & $\cdot$ & $\cdot$ & $\cdot$ & $\cdot$ & $\mathrm{C}$ & $\cdot$ & . \\
\hline Hap12 & . & . & . & . & . & $A$ & . & . & . & . & . & . & . & . & . & $G$ & . \\
\hline Hap13 & . & . & . & $A$ & . & . & . & . & . & . & . & . & . & . & . & . & $A$ \\
\hline Hap14 & . & . & $\cdot$ & $\cdot$ & . & . & . & . & . & . & . & $\cdot$ & $\cdot$ & $\cdot$ & $\cdot$ & $\cdot$ & $\cdot$ \\
\hline Hap15 & . & . & . & . & . & . & . & . & . & $\mathrm{G}$ & . & . & $A$ & . & . & . & . \\
\hline Hap16 & . & . & . & . & $A$ & . & . & . & . & . & . & . & . & . & . & . & . \\
\hline
\end{tabular}

Dots indicate that the nucleotide is identical to that in the Hap1 sequence. 


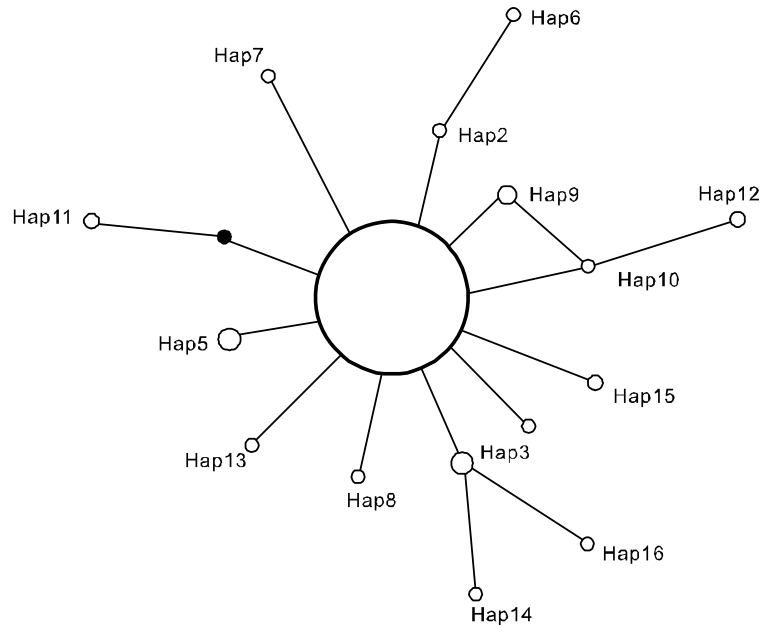

Fig. 2. A single minimum spanning tree of the 16 mtDNA Cytb haplotypes of Stephanolepis cirrhifer (Table 2). Circle sizes reflect haplotype abundances.

Table 3. Distribution of mtDNA Cytb haplotypes among five populations of Stephanolepis cirrhifer

\begin{tabular}{lrrrrrr}
\hline & Jeju & Yeosu & Geoje & Pohang & Uljin & Total \\
\hline Hap1 & 14 & 17 & 15 & 14 & 18 & 78 \\
Hap2 & 1 & 1 & 2 & & 1 & 5 \\
Hap3 & & 1 & 4 & 1 & 1 & 7 \\
Hap4 & 1 & & 1 & & 1 & 3 \\
Hap5 & & 2 & 2 & 1 & 1 & 6 \\
Hap6 & & 1 & & & & 1 \\
Hap7 & 1 & & & & & 1 \\
Hap8 & & 1 & & & 1 & 2 \\
Hap9 & 1 & & & & & 1 \\
Hap10 & 1 & & & & & 1 \\
Hap11 & 1 & & & & 1 & 1 \\
Hap12 & & & & 1 & & 1 \\
Hap13 & & & & 2 & & 2 \\
Hap14 & & & & 1 & & 1 \\
Hap15 & & & & 1 & & 1 \\
Hap16 & & & & & &
\end{tabular}

tinuously to high rates of gene flow from southern sources. The population structure of many marine fishes often depends on the active migration of adults and passive dispersal of larvae (Waples, 1998; Cowen et al., 2000, 2003). The major current along the Korean coast is the Tsushima Warm Current (TWC), which branches off the Kuroshio Current in the East China Sea, with part of the TWC running into the Yellow Sea and the main part entering the East Sea along the Korean Peninsula (Senjyu, 1999; Ichikawa and Beardsley, 2002). Thus, our results suggest that the TWC transports S. cirrhifer larvae in the East China Sea to the East Sea on the Korean coast.

Neutrality indices calculated for each population and the entire sample are shown in Table 4. With both tests used (Fu's $F_{S}$ and Tajima's $D$ ), the populations had negative values and deviated significantly from the neutral evolution model, except one. Fu's $F_{S}$ and Tajima's $D$ for the entire population were -15.07895 $(P<0.0001)$ and $-2.12964(P<0.0001)$, respectively. The mismatch distributions of all populations were unimodal (Fig. 3). All of our results suggest sudden population expansion.

Our study suggests that the migration and reproductive behavior of $S$. cirrhifer are similar to those of other marine fish species among which haplotypes with recently diverged nucleotides are distributed via the long-range dispersal of larvae among populations or regions (Sekino and Hara, 2001; Kim et al., 2010). Our findings support the notion that S. cirrhifer in the South Sea and East Sea Korean populations forms a single panmictic stock. Thus, the S. cirrhifer in the South Sea and East Sea Korean populations should be treated as one management unit. To have a comprehensive understanding of the population structure of S. cirrhifer, it is necessary to obtain more mtDNA sequence information by expanding the sampling areas around Korea and elsewhere in the Pacific Ocean.

Table 4. Measures of mtDNA diversity and neutrality indices calculated for each population of Stephanolepis cirrhifer

\begin{tabular}{lccccc}
\hline Sampling site & No. of haplotypes & $\begin{array}{c}\text { Haplotype diversity } \\
(h, \pm \text { SD })\end{array}$ & $\begin{array}{c}\text { Nucleotide diversity } \\
(\pi)\end{array}$ & $\begin{array}{c}\text { Fu's } F_{S} \\
(P \text {-value })\end{array}$ & $\begin{array}{c}\text { Tajima's } D \\
(P \text {-value })\end{array}$ \\
\hline Jeju & 7 & $0.521 \pm 0.135$ & 0.00161 & $-4.45301^{*}$ & $-1.96358^{*}$ \\
Yeosu & 8 & $0.504 \pm 0.123$ & 0.00149 & $-4.35828^{*}$ & $-1.89914^{*}$ \\
Geoje & 5 & $0.591 \pm 0.104$ & 0.00140 & -1.85358 & -0.96799 \\
Pohang & 7 & $0.562 \pm 0.126$ & 0.00199 & $-3.50931^{*}$ & $-1.60753^{*}$ \\
Uljin & 7 & $0.446 \pm 0.126$ & 0.00118 & $-5.34756^{*}$ & $-2.15287^{*}$ \\
Entire & & $0.5172 \pm 0.057$ & 0.00153 & $-15.07895^{*}$ & $-2.12964^{*}$ \\
\hline
\end{tabular}

*Significant differentiation $(P<0.05)$.

South Sea, with part of the TWC running into the Korea. 
Table 5. Pairwise $F_{\mathrm{ST}}$ estimates among the five populations of Stephanolepis cirrhifer , "-" is no significant differentiation $(P>0.05)$. Probability of differentiation with $P$ value was calculated from 1,000 replications

\begin{tabular}{lccccc}
\hline & Jeju & Yeosu & Geoje & Pohang & Uljin \\
\hline Jeju & & - & - & - & - \\
Yeosu & -0.009 & & - & - & - \\
Geoje & 0.026 & -0.008 & & - & - \\
Pohang & 0.039 & 0.020 & -0.010 & & - \\
Uljin & -0.017 & -0.021 & -0.004 & 0.019 & \\
\hline
\end{tabular}

Table 6. Results of the hierarchical analysis of molecular variance (AMOVA) based on mtDNA Cytb sequence data for Stephanolepis cirrhifer

\begin{tabular}{lrcccc}
\hline Source of variation & \multicolumn{1}{c}{$\mathrm{df}$} & Sum of squares & Variance components & Percentage of variation & $F$ index $(P)$ \\
\hline Among population & 4 & 1.639 & $0.00155 \mathrm{Va}$ & 0.41 & $0.00412(P>0.05)$ \\
Within population & 108 & 40.485 & $0.37486 \mathrm{Vb}$ & 99.59 & \\
\hline Total & 112 & 42.124 & 0.37641 & & \\
\hline
\end{tabular}

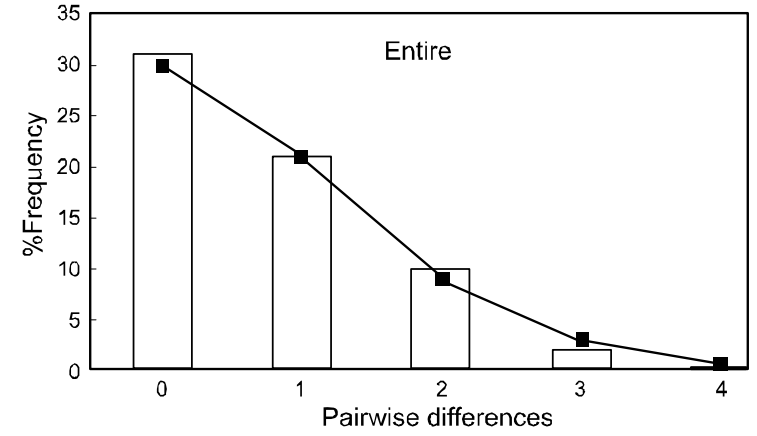

Fig. 3. Mismatch distribution of Stephanolepis cirrhifer population in the south and east coast Korean peninsula. Bar graph: observed mismatch distribution; line graph: expected distribution for sudden expansion model.

\section{Acknowledgments}

This study was supported by a research grant (project no. \#20088033-1) from the Ministry of Land, Transport, and Maritime Affairs, of the Republic of Korea.

\section{References}

Avise JC. 1994. Molecular Markers, Natural History and Evolution. Chapman \& Hall, New York.

Avise JC. 2000. Phylogeography: the History and Formation of Species. Harvard University Press, Cambridge, MA.

Bailey KM. 1997. Structural dynamics and ecology of flatfish populations. Neth J Sea Res 37, 269-280.

Clement M, Posaka D and Crandall KA. 2000. TCS: a computer program to estimate gene genealogies. Mol Ecol 9, 1657-1659.
Cowen RK, Lwiza KMM, Sponaugle S, Paris CB and Olson DB. 2000. Connectivity of marine populations: open or closed? Science 287, 857-859.

Cowen RK., Paris CB, Olson DB and Fortuna JL. 2003. The role of long distance dispersal in replenishing marine populations. Gulf Caribb Rec 14, 129-137.

Doyle MJ, Morse WW and Kendall Jr AW. 1993. A comparison of larval fish assemblages in the temperate zone of the northeast Pacific and northwest Atlantic Oceans. Bull Mar Sci 53, 588-644.

Excoffier L, Laval G and Schneider S. 2005. Arlequin ver. 3.0: an integrated software package for population genetics data analysis. Evol Bioinform 1, 47-50.

FAO. 2004. Depleted marine resources: an approach to quantification based on the FAO capture database. FAO Fisheries Circular, No. 1011: 18-19. Rome, Fisheries and Aquaculture Organization. Department, Fishery Information, Data and Statistics Unit.

Frankel OH and Soulé ME. 1981. Conservation and Evolution. New York, NY: Cambridge University Press.

Grant WS and Bowen BW. 1998. Shallow population histories in deep evolutionary lineages of marine fishes: insights from sardines and anchovies and lessons for conservation. J Hered 89, 415-426.

Hamner RM, Freshwater DW and Whitfield PE. 2007. Mitochondrial cytochrome $\mathrm{b}$ analysis reveals two invasive lionfish species with strong founder effects in the western Atlantic. J Fish Biol 71(Supplement B), 214-222.

Hsieh HY, Lo WT, Liu DC and Su CW. 2010. Influence of hydrographic features on larval fish distribution during the south-westerly monsoon in the waters of Taiwan, western North Pacific Ocean. J Fish Biol 76, 2521-2539.

Hwa H, Ko T, Chen Y, Chang Y, Tseng L, Su Y and Lee J. 
2009. Study of the cytochrome b gene sequence in populations of Taiwan. J Forensic Sci 55, 167-170.

Ichikawa $\mathrm{H}$ and Beardsley RC. 2002. The current system in the Yellow and East China Seas. J Oceanogr 58, 77 92.

Kim W-J, Kim K-K, Han H-S, Nam B-H, Kim Y-O, Kong H-J, Noh J-K and Yoon M. 2010. Population structure of the olive flounder (Paralichthys olivaceus) in Korea inferred from microsatellite marker analysis. J Fish Biology 76, 1958-1971.

Kochzius M and Blohm D. 2005. Genetic population structure of the lionfish Pterois miles (Scorpaenidae, Pteroinae) in the Gulf of Aqaba and northern Red Sea. Gene 347, 295-301.

Lessios HA, Kessing BD and Pearse JS. 2001. Population structure and speciation in tropical seas: global phylogeography of the sea urchin Diadema. Evolution 55, 955-975.

Masuda H, Amaoka K, Araga C, Uyeno T and Yoshino T. 1984. The fishes of the Japanese Archipelago. Tokai University Press, Tokyo, Japan, p. 437.

McElroy D, Moran P, Bermingham E and Kornfield I. 1993. REAP: An integrated environment for the manipulation and phylogenetic analysis of restriction data. J Hered 83, 157-158.

Moritz C, Dowling TW and Brown WM. 1987. Evolution of animal mitochondrial DNA: relevance for population biology and systematic. Ann Rev Ecol Syst 18, 269-292.

Nei M. 1987. Molecular Evolutionary Genetics. Columbia University Press, New York.

Palumbi SR. 1994. Genetic divergence, reproductive isolation, and marine speciation. Annu Rev Ecol Syst 25, 547-572.

Rogers AR. and Harpending H. 1992. Population growth makes waves in the distribution of pairwise genetic differences. Mol Biol Evol 9, 552-569.

Rozas J and Rozas R. 1997. DnaSP version 2.0: a novel software package for extensive molecular population genetics analysis. Comput Appl Biosci 13, 307-311.

Sambrook J and Russell DW. 2001. Molecular Cloning, A
Laboratory Manual. 3rd Ed. Cold Spring Harbor Press, New York.

Schneider S, Roessli D and Excoffier L. 2000. Arlequin: a software for popula-tion genetics data analysis. User manual ver 2.000. Genetics and Bi-ometry Lab, Dept. of Anthropology, University of Geneva, Geneva.

Sekino M. and Hara M. 2001. Application of microsatellite markers to population genetics studies of Japanese flounder Paralichthys olivaceus. Mar Biotechnol 3, 572-589.

Senjyu T. 1999. The Japan Sea intermediate water; its characteristics and circulation. J Oceanogr 55, 111122.

Slatkin M and Hudson RR. 1991. Pairwise comparisons of mitochondrial DNA sequences in stable and exponentially growing populations montgomery. Genetics 129, 555-562.

Song N, Zhang XM, Sun XF, Yanagimoto T and Gao TX. 2010. Population genetic structure and larval dispersal potential of spottedtail goby Synechogobius ommaturus in the north-west Pacific. J Fish Biol 77, $388-402$.

Umino T, Kajihara T, Shiozaki H, Ohkawa T, Jeong DS and Ohara K. 2009. Wild stock structure of Girella punctata in Japan revealed shallow genetic differentiation but subtle substructure in subsidiary distributions. Fish Sci 75, 909-919.

Waples RS. 1998. Separating the wheat from the chaff: patterns of genetic differentiation in high gene flow species. J Hered 89, 438-450.

Youn C-H. 2002. Fishes of Korea with Pictorial Key and Systematic List. Academic Seojeok, Seoul. 448, 694 $\mathrm{pp}$

Zhang J, Cai Z and Huang L. 2006. Population genetic structure of crimson snapper Lutjanus erythropterus in East Asia, revealed by analysis of the mitochondrial control region. ICES J Mar Sci 63, 693-704.

(Received 27 December 2010; Revised 28 February 2011; Accepted 8 March 2011) 